\title{
The effect of perceptions of corporate identity and corporate social responsibility practices on investment intention
}

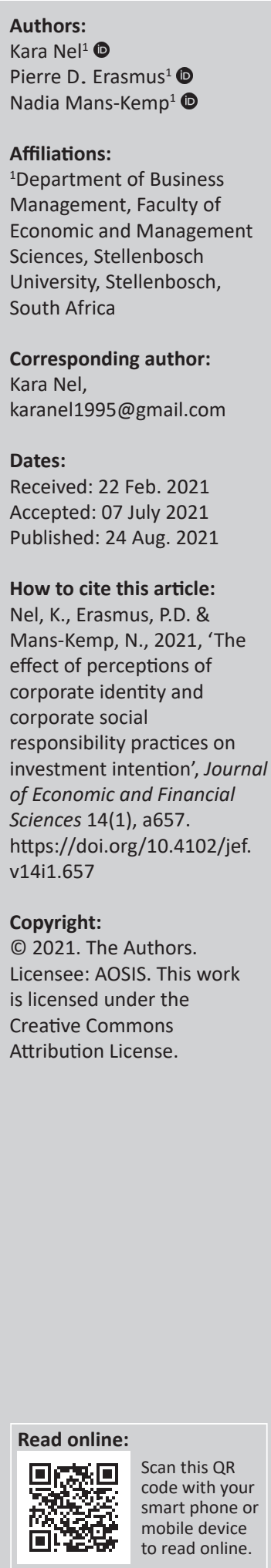

Orientation: Given the growing importance of sound corporate social responsibility (CSR) and considerable corporate investment in such activities, it is essential to understand the perceived impact thereof on stakeholder behaviour.

Research purpose: As young individuals are particularly passionate about social responsibility, the effect of their perception of corporate identity (corporate values and corporate expertise) and CSR practices (relational, moral and discretionary actions) on their investment intention was investigated within an emerging market context.

Motivation for the study: Previous researchers mainly focused on the effects of CSR on consumers' intention to purchase products. Limited research has been conducted to understand the effect of CSR on decisions made by other key stakeholders, including investors.

Research approach/design and method: Based on the theory of planned behaviour, a consumer behaviour-based dual-process model was adapted and tested in the investment context. An electronic questionnaire was distributed to potential young investors in the country to determine the effect of their perceptions of the CSR practices of a well-known South African financial company (Nedbank) on their intention to invest. The 1649 responses were assessed through partial least squares structural equation modelling.

Main findings: The adapted model was deemed reliable and valid in the investment context. Discretionary and relational CSR practices had more predictive relevance towards the corporate values dimension than the corporate expertise dimension of corporate identity. Moral CSR practices predicted the perception of both dimensions, which, in turn, influenced investment intention.

Practical/managerial implications: Focus should be placed on communicating moral CSR practices, as it had a stronger prediction value (than discretionary and relational CSR practices) towards potential investors' perceptions of the corporate expertise and values dimension of corporate identity which, in turn, strongly predicted investment intention.

Contribution/value-add: This study makes a methodological contribution, as a dual-process model accounting for corporate identity and a range of CSR practices, based on consumer behavioural constructs, was applied in the context of investment decision-making within an emerging market.

Keywords: corporate identity; CSR; investment intention; perception; theory of planned behaviour; young individuals.

\section{Introduction}

\section{According to Porter and Kramer (2006):}

[I]f corporations were to analyse their prospects for social responsibility using the same framework that guide their core business choices, they would discover that it can be much more than a cost, a constraint, or a charitable deed - it can be a source of opportunity, innovation, and competitive advantage. (p. 80)

Porter and Kramer (2011) also emphasised that investing in social responsibility can result in shared value creation for several stakeholders, including investors, consumers and employees.

A growing number of companies around the globe are acknowledging the benefits of corporate social responsibility (CSR) and invest in such activities to, inter alia, generate financial returns, cultivate a favourable reputation and improve employee productivity (Dowling \& Moran 2012). 
Fortune Global 500 firms spend approximately $\$ 20$ billion per annum on CSR activities (Meier \& Cassar 2018). Given the importance of and considerable corporate investment in CSR activities, it is essential to understand how different stakeholders' perceptions of such activities can impact their decision-making.

Based on the theory of planned behaviour, researchers should account for attitude when investigating human behaviour (Ajzen 1991; Fishbein \& Ajzen 1975; Parumasur \& Roberts-Lombard 2014). This theory asserts that attitude (which comprises perception), subjective norms and perceived behavioural control influence intention. In turn, intention influences human behaviour and their decisionmaking processes (Ajzen 1991; East 1993).

Previous authors have mainly evaluated the effects of CSR on customers' intent to purchase products (Brown \& Dacin 1997; David, Kline \& Dai 2005). Sen and Bhattacharya (2001) argued that consumers' perceptions of corporate characteristics play a mediating role in this regard. Individuals' perceptions of products and brands might furthermore play a role in their investment decisions (ClarkMurphy \& Soutar 2004; Frieder \& Subrahmanyam 2005; Lim, Soutar \& Lee 2013). Corporate expertise and corporate values are critical to a company's identity, which is linked to its corporate branding. In turn, a strong corporate identity can make an organisation more attractive to investors (Melewar \& Karaosmanoglu 2006).

Aspara and Tikkanen (2008) suggest that individuals' attitudes towards a company, their tendency to invest in a company's shares and their propensity to buy its products are likely to interact. Investors' experiences with a company's products and identification with the company's actions furthermore play a role in their investment decision-making (Aspara \& Tikkanen 2010; Brown \& Dacin 1997; Lim et al. 2013). In a developed market, Arikan et al. (2016) found that corporate reputation mediates the relationship between CSR and purchase intention and the intention to seek employment. Additionally, they found that corporate reputation partially mediates the relationship between CSR and investment intention. Although several researchers focussed on purchasing intention, limited attention has been given to the impact of perception on investment intention, especially in the emerging market context.

Given the close relationship between behavioural finance and consumer behaviour, some researchers proposed that consumer theories and marketing research techniques could be used to study investors' decision-making (Lim et al. 2013; Statman 2004). David et al. (2005) developed a dual-process model incorporating corporate identity and CSR perception to investigate consumers' purchasing intent. In the current study, this model has been adapted by replacing the purchase intention construct with investment intention to assess the role of perception of corporate identity and CSR practices on investment intention in South Africa. An electronic survey was distributed to a sample of potential young investors at a local university. Their perceptions of the corporate identity and CSR practices of Nedbank, a well-known South African financial company, and the impact thereof on their investment intention, were evaluated.

It is debatable whether students could automatically be deemed potential future investors. Although student participants might not be involved in actual investment activities whilst they are studying and might hence not be representative of the average investor, they will arguably generate income in future and are expected to invest some of these earnings in financial markets. Hence, they might have the intention to invest in companies (Sen, Bhattacharya \& Korschun 2006). Alniacik, Alniacik and Genc (2011) likewise argued that as students are prospective investors, they might view themselves as stakeholders of a specific company in the investment domain. Young individuals are furthermore typically sensitive to CSR issues (deVere Group 2020; Sen et al. 2006). As such, social consumerism and socially responsible investment have been linked to young consumers and investors (Diamantopoulos et al. 2003; Junkus \& Berry 2010; Nilsson 2008). Students are therefore likely to account for CSR performance when reflecting on investment decisions.

The 1649 responses to the electronic questionnaire were assessed through partial least squares structural equation modelling (PLS-SEM). The results show that CSR discretionary and relational practices had more predictive relevance towards corporate values than corporate expertise. The perception of both dimensions was strongly predicted by moral CSR practices, which, in turn, strongly predicted investment intention amongst the sampled potential young investors. The results suggest that if corporate role players develop a better understanding of the factors that impact investment intention, (more) enduring relationships can be developed. CSR initiatives can be used as a strategic tool to impact young investors' perception of a company's corporate identity and, in turn, influence their investment intention. The results hence show support for the application of the theory of planned behaviour in the investment context.

In the remainder of this article, the selected theory will be explained, and an overview of the literature will be provided to develop hypotheses. Thereafter, the methodology and results will be explained. Recommendations are then offered to a range of stakeholders based on the conclusions.

\section{Theoretical perspectives}

Traditional finance theories are grounded on the assumption that rational investors base their decisions purely on riskreturn considerations. In contrast, behavioural finance theory suggests that attitudes towards a particular firm could influence investment intention (East 1993). Risk and return considerations are relatively easy to quantify, but the complex nature of the mental space between the known and the unknown (perception) makes it challenging to describe the latter phenomenon (Brown 2015). 
Some scholars who investigated stakeholder decisionmaking and behaviour accounted for perception by referring to the rational choice theory, signalling theory and the theory of planned behaviour. The rational choice theory states that individuals are likely to calculate the costs and benefits of planned actions before they make a selection (Scott 2000). Based on this theory, researchers have shown that when individuals evaluate their behavioural intentions, for example by purchasing products from a company, their perceptions of the company's identity are likely to influence their decision-making processes (David et al. 2005).

Other authors have relied on the signalling theory to evaluate stakeholder decisions (Arikan et al. 2016; Turban \& Greening 1997). This theory argues that corporate communication with different stakeholders influence their behaviour. The socalled corporate signals can hence modify the behaviour of stakeholders to benefit companies, for instance through enlarging their customer bases (Connelly et al. 2011).

The theory of planned behaviour was developed to understand and predict human behaviour based on attitude and intention (Ajzen 1991). This theory asserts that behavioural intention determines the behaviour of individuals. In turn, behavioural intention is influenced by attitude (which comprises perception), subjective norms and perceived control (Ajzen 1991). Prior authors have applied the theory of planned behaviour in the investment context, specifically to assess socially responsible investment decisionmaking (Adam \& Shuaki 2014; Alleyne \& Broom 2011; East 1993). As such, this theory was selected to examine investment intention in South Africa based on CSR perceptions.

\section{Literature review and hypotheses development}

The theory of planned behaviour states that attitude is a pertinent psychological aspect related to perception that has a considerable influence on individual behaviour (Ajzen 1991). Attitude and perception will hence be discussed next. The impact of perception of corporate identity and CSR on investment decision-making will then be explored to derive 18 hypotheses.

\section{Attitude and perception}

Hogg and Vaughan (2008:150) described attitude as a 'relatively enduring organisation of beliefs, feelings, and behavioural tendencies towards socially significant objects, groups, events, or symbols'. Attitude is composed of affective, behavioural and cognitive components (Jain 2014). The first component involves an individual's feelings and recognition of an object (Zikmund et al. 2013). The behavioural component refers to the response that has the attitude object as a result (Ajzen 1989). The last component involves an individual's beliefs, knowledge or perception of the object (Jain 2014).

Erasmus (2017) found that the affective and cognitive components predominantly impact young investors' decision-making. The cognitive component is strongly influenced by perception (Ajzen 1989). According to Reitz (1977), perception includes those processes by which individuals receive information about their environments. Perception is also based on individuals' frames of reference, because prior experiences form part of the perception of stimuli (Schiffman \& Kanuk 2010).

The perceptual process consists of four stages, namely exposure, attention, interpretation and memory. Exposure refers to individuals becoming aware of stimuli in their environments (Parumasur \& Roberts-Lombard 2014). During the second stage, processing is devoted to a particular stimulus resulting from the functioning of sensory systems (Foley \& Matlin 2010). Individuals assign meaning to a particular stimulus during the interpretation stage. By using memory, they identify, select and use information. This information forms the basis of individuals' perceptions, which form part of their attitude and which can impact their behaviour (Albarracin 2002; Maio \& Haddock 2015). When attempting to improve the understanding of investment behaviour, it is thus essential to account for perception.

\section{Linking corporate identity to investment decision-making}

Stakeholders' perception of an organisation's corporate identity plays an important role in their decision-making processes (Brown \& Dacin 1997). Corporate identity is defined as an organisation's central, distinctive and enduring character perceived by its stakeholders (Schmidt 1995). The construct has been divided into corporate expertise and corporate values to capture the essence thereof within various study fields.

Corporate expertise is defined as the ability of a company to detect, assess and satisfy needs by being the leader in a product or service category (David et al. 2005). Corporate expertise includes tangible and intuitive factors such as the experience and skills of leaders (Brown \& Dacin 1997; David et al. 2005). The corporate expertise dimension is driven by willing transactions between the organisation and its stakeholders, whereas the corporate values dimension is driven by discretionary practices that aim to improve societal issues (David et al. 2005).

Consumers, employees and investors increasingly become concerned with purchasing products from, seeking employment with and investing in companies that demonstrate a socially and environmentally responsible image (Alniacik et al. 2011). Young individuals are particularly passionate about social responsibility (deVere Group 2020). The corporate values dimension of corporate identity hence warrants more attention. This dimension focusses on social values with the goal to improve the well-being of society and the environment. It is represented by the organisation's commitment to moral, ethical, social and environmental obligations (David et al. 2005).

Related traits include compassion, activism, sincerity and trustworthiness (David et al. 2005). Compassion entails the 
intent to contribute to the well-being of others (Valdellon 2018), whilst activism involves taking a public stance to positively impact social change (Disparte \& Gentry 2015). Sincerity refers to genuinely caring for stakeholders (Oswald 2010). Trustworthiness involves being able to rely on or have confident expectations of the honesty of an individual or a company (Wittmer \& O’Brien 2014).

Given that a strong corporate identity can attract investors (Melewar \& Karaosmanoglu 2006), the following hypotheses were developed to assess the effect of the corporate expertise and value dimensions of corporate identity on investment intention:

$\mathbf{H}_{1}$ : The perception of corporate expertise has a positive effect on investment intention.

$\mathbf{H}_{2}$ : The perception of corporate values has a positive effect on investment intention.

According to David et al. (2005), perception of CSR practices can have an impact on both dimensions of corporate identity. In turn, they found that corporate identity impacts stakeholder intention. As such, it can be postulated that corporate identity is a mediating factor when accounting for the effect of CSR perception on decision-making.

\section{Exploring the links between corporate social responsibility, corporate identity and investment intention}

According to Carroll (1979), the social responsibility of a company encompasses society's economic, legal, ethical and discretionary expectations. Corporate reputation is regarded as one of the main drivers for companies to invest in CSR activities (Kurucz, Colbert \& Wheeler 2008; Maruf 2013). Information about CSR activities furthermore provides stakeholders with insight into a company's value system and character (Brown \& Dacin 1997).

CSR activities can be divided into moral, discretionary and relational practices. Moral practices involve norms, standards, values and expectations that reflect what stakeholders regard as fair, just and consistent with moral rights (Carroll \& Buchholtz 2015). Discretionary practices refer to philanthropic responsibilities, whilst relational practices refer to the relationship between a company and its stakeholders regarding social issues (Carroll \& Buchholtz 2015). As David et al. (2005) noted that CSR practices are significant predictors of corporate identity, the following six hypotheses were developed to assess the effect of CSR practices on the expertise and value dimensions of corporate identity:

$\mathbf{H}_{3}$ : Discretionary CSR practices have a positive effect on corporate expertise.

$\mathbf{H}_{4}$ : Discretionary CSR practices have a positive effect on corporate values.

$\mathbf{H}_{5}$ : Moral CSR practices have a positive effect on corporate expertise.

$\mathbf{H}_{6}$ : $\quad$ Moral CSR practices have a positive effect on corporate values.
$\mathrm{H}_{7}: \quad$ Relational CSR practices have a positive effect on corporate expertise.

$\mathbf{H}_{8}$ : Relational CSR practices have a positive effect on corporate values.

In response to the growing number of organisations that are introducing CSR initiatives, researchers started to focus on the impact thereof on stakeholders, in particular customers, and established that CSR actions affected customers' evaluation of a particular firm (Brown \& Dacin 1997; David et al. 2005; Sen \& Bhattacharya 2001). Mackey, Mackey and Barney (2007) reasoned that the opportunity to invest in a firm engaging in CSR is a 'product' that firms sell to current and potential investors. This notion warrants further investigation.

David et al. (2005) postulated that the effect of discretionary, moral and relational CSR practices on consumer decisionmaking is mediated by the discussed corporate identity dimensions. Hypotheses 9 to 14 were hence developed to assess whether the respective CSR practices influence investment intention through corporate identity:

$\mathbf{H}_{9}$ : The influence of discretionary CSR practices on investment intention is mediated by corporate expertise, such that the indirect effect is positive.

$\mathbf{H}_{10}$ : The influence of discretionary CSR practices on investment intention is mediated by corporate values, such that the indirect effect is positive.

$\mathbf{H}_{11}$ : The influence of moral CSR practices on investment intention is mediated by corporate expertise, such that the indirect effect is positive.

$\mathbf{H}_{12}$ : The influence of moral CSR practices on investment intention is mediated by corporate values, such that the indirect effect is positive.

$\mathbf{H}_{13}$ : The influence of relational CSR practices on investment intention is mediated by corporate expertise, such that the indirect effect is positive.

$\mathrm{H}_{14}$ : The influence of relational CSR practices on investment intention is mediated by corporate values, such that the indirect effect is positive.

Although sound CSR practices can considerably strengthen an entity's corporate image, stakeholders are not per se aware of a company's CSR initiatives (Bhattacharya, Sen \& Korschun 2008). Pérez and Rodríguez del Bosque (2012) hence emphasised the importance of clear communication to facilitate the transmission of information on corporate identity linked to CSR. According to David et al. (2005), the CSR practices of a company have an impact on its CSR familiarity. In turn, CSR familiarity can have a positive impact on stakeholder intention, either directly or indirectly through the two corporate identity dimensions. Hypotheses 15 to 17 were therefore developed to assess the indirect and direct effects of CSR familiarity on investment intention:

$\mathbf{H}_{15}$ : The influence of CSR familiarity on investment intention is mediated by corporate expertise, such that the indirect effect is positive. 
$\mathrm{H}_{16}$ : The influence of CSR familiarity on investment intention is mediated by corporate values, such that the indirect effect is positive.

$\mathbf{H}_{17}$ : CSR familiarity has a positive direct effect on investment intention.

David et al. (2005) furthermore reported that brand familiarity had a positive impact on consumers' intention to purchase products. Hypothesis 18 was hence formulated to account for the impact of brand familiarity on investment intention:

$\mathbf{H}_{18}$ : Brand familiarity has a positive effect on investment intention.

The positivist paradigm was adopted to test the formulated hypotheses, as explained next, based on the philosophy that observation and reason are the means of understanding human behaviour (Henning, Van Rensburg \& Smit 2004).

\section{Research design and methodology}

An appropriate South African-based company had to be identified to assess the role that perception of corporate identity and CSR practices play in potential young South African investors' investment intention. As such, exploratory research was conducted by distributing a paper-based survey amongst the participants of a focus group, comprising business management post-graduate students at a South African university, to explore which company should be included in the electronic survey.

\section{Development and dissemination of the paper- based survey}

The focus group's unaided recall of a South African company with a good CSR reputation was tested. Four aspects were taken into account when selecting companies for inclusion in the paper-based survey. Firstly, large, familiar companies were considered, because brand familiarity forms part of the dual-process model. Media articles on South Africa's leading and most valuable brands were consulted to identify such companies. Secondly, companies that are perceived as leaders in their industry were chosen to address the expertise dimension of corporate identity. Thirdly, companies that recently (2018-2019) received press coverage on their CSR initiatives were considered. Fourthly, banks, retailers and mobile network providers that met the aforementioned criteria were considered because young individuals engage with such companies on a regular basis.

A well-known South African financial company known for its CSR initiatives, Nedbank, was selected based on the focus group's responses. Thereafter, the interactions between brand familiarity, CSR familiarity, CSR practices, corporate identity and intention to invest in Nedbank were examined by means of an electronic survey. This survey was based on the dual-process model suggested by David et al. (2005), as explained in the next section.

\section{Development and dissemination of the electronic survey}

The first part of the adapted dual-process model proposed by David et al. (2005) accounts for the bond between an investor and Nedbank in terms of both dimensions of corporate identity. As explained, the corporate expertise dimension includes specific traits, namely expert, skilled, experienced and innovative. The corporate values dimension focusses on CSR values, namely activist, compassionate, sincere and trustworthy (David et al. 2005).

The second part of the model incorporates potential investors' perceptions of specific CSR practices (discretionary, moral and relational actions). Corporate identity is now regarded as a mediating variable that links CSR practices with investment intention. As the minimum requirement for CSR activities to have an effect on corporate identity and investment intention

TABLE 1: Electronic questionnaire content.

\begin{tabular}{|c|c|c|c|}
\hline Constructs & Measurement & Question(s) & Likert scale options \\
\hline Brand familiarity & $\begin{array}{l}\text { A well-known South } \\
\text { African company, } \\
\text { Nedbank, was } \\
\text { selected based on } \\
\text { the focus group's } \\
\text { responses. }\end{array}$ & $\begin{array}{l}\text { How familiar are } \\
\text { you with } \\
\text { Nedbank? }\end{array}$ & $\begin{array}{l}\text { Not at all familiar } \\
\text { to very familiar }\end{array}$ \\
\hline $\begin{array}{l}\text { Perception of the } \\
\text { company's } \\
\text { corporate identity }\end{array}$ & $\begin{array}{l}\text { The corporate } \\
\text { identity scale } \\
\text { developed by David } \\
\text { et al. (2005) was } \\
\text { applied; the scale } \\
\text { presented } \\
\text { respondents with } \\
\text { eight traits: } \\
\text { Corporate expertise: } \\
\text { expert, skilled, } \\
\text { experienced, } \\
\text { innovative; Corporate } \\
\text { values: activist, } \\
\text { compassionate, } \\
\text { sincere, trustworthy. }\end{array}$ & $\begin{array}{l}\text { In your opinion, } \\
\text { to what extent } \\
\text { does each of the } \\
\text { following traits } \\
\text { describe } \\
\text { Nedbank? }\end{array}$ & $\begin{array}{l}\text { Does not describe } \\
\text { the company to } \\
\text { accurately } \\
\text { describes the } \\
\text { company }\end{array}$ \\
\hline $\begin{array}{l}\text { Respondent's } \\
\text { perception of the } \\
\text { importance of CSR } \\
\text { practices (in } \\
\text { general) }\end{array}$ & $\begin{array}{l}\text { Based on the CSRHub } \\
\text { sub-categories (refer } \\
\text { to Table 2). }\end{array}$ & $\begin{array}{l}\text { In your opinion, } \\
\text { how important is } \\
\text { each of these } \\
\text { attributes when } \\
\text { you think about } \\
\text { the CSR concept? }\end{array}$ & $\begin{array}{l}\text { Not at all } \\
\text { important to very } \\
\text { important }\end{array}$ \\
\hline $\begin{array}{l}\text { Perception of the } \\
\text { company's CSR } \\
\text { practices }\end{array}$ & $\begin{array}{l}\text { Based on the CSRHub } \\
\text { sub-categories (refer } \\
\text { to Table 2). }\end{array}$ & $\begin{array}{l}\text { Please rate how } \\
\text { you think the } \\
\text { Nedbank } \\
\text { performs relating } \\
\text { to the indicated } \\
\text { CSR practices. }\end{array}$ & $\begin{array}{l}\text { Performs very } \\
\text { poorly to } \\
\text { performs very well }\end{array}$ \\
\hline CSR familiarity & $\begin{array}{l}\text { Awareness of } \\
\text { Nedbank's CSR } \\
\text { actions that were } \\
\text { recently ( } 2018 / 2019) \\
\text { mentioned in the } \\
\text { media and/or } \\
\text { reported by the } \\
\text { company. }\end{array}$ & $\begin{array}{l}\text { Please indicate } \\
\text { how familiar you } \\
\text { are with the } \\
\text { indicated CSR } \\
\text { practices of } \\
\text { Nedbank. }\end{array}$ & $\begin{array}{l}\text { Not at all familiar } \\
\text { to very familiar }\end{array}$ \\
\hline $\begin{array}{l}\text { Investment } \\
\text { intention }\end{array}$ & $\begin{array}{l}\text { Investment intention } \\
\text { was measured at } \\
\text { three stages in the } \\
\text { questionnaire. Firstly, } \\
\text { purely based on the } \\
\text { respondents' } \\
\text { perception of } \\
\text { Nedbank's CSR } \\
\text { practices. Secondly, } \\
\text { the respondents } \\
\text { were presented with } \\
\text { Nedbank's actual CSR } \\
\text { practices. Thirdly, the } \\
\text { respondents were } \\
\text { provided with a } \\
\text { concrete CSR rating } \\
\text { for Nedbank on the } \\
\text { CSRHub (2019) } \\
\text { database. }\end{array}$ & $\begin{array}{l}\text { Please indicate } \\
\text { how likely you are } \\
\text { to invest in } \\
\text { Nedbank's shares. }\end{array}$ & $\begin{array}{l}\text { Very unlikely to } \\
\text { very likely }\end{array}$ \\
\hline
\end{tabular}

CSR, corporate social responsibility. 
is familiarity with CSR activities (David et al. 2005), the model also accounts for CSR familiarity and brand familiarity.

Table 1 provides details on the constructs and Likert scale options included in the electronic questionnaire. Nedbank's 2018 Sustainability Development Review was consulted to obtain details on its actual CSR practices. Nedbank's CSR rating, based on its impact on the environment, employees, community and governance, was obtained from CSRHub (2019). Information sourced from this database was also used to select 13 CSR practices, classified as relational, moral or discretionary (refer to Table 2).

After ethical clearance was obtained from the applicable research ethics committee (REC-2019-9950), institutional permission (IRPSD-1581) was obtained to distribute the electronic questionnaire by means of an email message to all students (30 563 individuals) studying at the selected South African university during the second semester of 2019. Nonprobability convenience sampling was employed, as participation in the study was voluntary and all students enrolled at the university had a student email address based on their student number that was conveniently available at the Registrar's office.

Demographic questions focussed on age, gender, education level and field of study. The questionnaire took approximately 20 min to complete. The Nedbank logo and matrix tables were included to visually improve the presentation. As all questions were mandatory, no incomplete responses could

TABLE 2: Corporate social responsibility practices measurement items.

\begin{tabular}{|c|c|c|c|}
\hline Domains & Sub-categories & CSR practices & $\begin{array}{l}\text { CSR practice } \\
\text { categories }\end{array}$ \\
\hline \multirow[t]{4}{*}{ Community } & \multirow{2}{*}{$\begin{array}{l}\text { Community } \\
\text { development and } \\
\text { philanthropy }\end{array}$} & $\begin{array}{l}\text { 1: Contribute to the } \\
\text { community }\end{array}$ & Discretionary \\
\hline & & $\begin{array}{l}\text { 2: Allow time for staff } \\
\text { to do volunteer } \\
\text { work }\end{array}$ & Discretionary \\
\hline & $\begin{array}{l}\text { Product development } \\
\text { and impact on society } \\
\text { at large }\end{array}$ & $\begin{array}{l}\text { 3: Do not produce } \\
\text { harmful products or } \\
\text { services }\end{array}$ & Moral \\
\hline & Human rights & $\begin{array}{l}\text { 4: Respect human } \\
\text { rights }\end{array}$ & Moral \\
\hline \multirow[t]{3}{*}{ Employees } & $\begin{array}{l}\text { Compensation and } \\
\text { benefits }\end{array}$ & $\begin{array}{l}\text { 5: Provide fair } \\
\text { compensation }\end{array}$ & Moral \\
\hline & $\begin{array}{l}\text { Diversity and labour } \\
\text { rights }\end{array}$ & $\begin{array}{l}\text { 6: Stand against } \\
\text { discrimination }\end{array}$ & Moral \\
\hline & $\begin{array}{l}\text { Training, health and } \\
\text { safety }\end{array}$ & $\begin{array}{l}\text { 7: Provide a healthy } \\
\text { work environment }\end{array}$ & Moral \\
\hline \multirow[t]{3}{*}{ Environment } & $\begin{array}{l}\text { Energy and climate } \\
\text { change }\end{array}$ & $\begin{array}{l}\text { 8: Address climate } \\
\text { change }\end{array}$ & Moral \\
\hline & $\begin{array}{l}\text { Environment policy } \\
\text { and reporting }\end{array}$ & $\begin{array}{l}\text { 9: Report on } \\
\text { environmental } \\
\text { impact }\end{array}$ & Relational \\
\hline & Resource management & $\begin{array}{l}\text { 10: Act in an } \\
\text { environmentally } \\
\text { friendly manner }\end{array}$ & Moral \\
\hline \multirow[t]{3}{*}{ Governance } & Board & $\begin{array}{l}\text { 11: Have a diverse } \\
\text { board of directors }\end{array}$ & Moral \\
\hline & Leadership ethics & $\begin{array}{l}\text { 12: Have healthy } \\
\text { relationships with } \\
\text { stakeholders }\end{array}$ & Relational \\
\hline & $\begin{array}{l}\text { Transparency and } \\
\text { reporting }\end{array}$ & $\begin{array}{l}\text { 13: Do not engage in } \\
\text { unethical practices }\end{array}$ & Moral \\
\hline
\end{tabular}

Source: Adapted from CSRHub, 2019, Software and database, viewed 01 March 2019, from https://www.csrhub.com/

CSR, corporate social responsibility. be submitted. The 1649 usable questionnaires that were received represented a response rate of $5.40 \%$.

\section{Data analysis, validity and reliability}

The interrelationships between the variables were assessed through PLS-SEM analysis. This method accommodates constructs that are measured by a few or single items (e.g. brand familiarity and investment intention). The variance inflation factor values ranged between 1.15 and 2.53, suggesting that multicollinearity was not a concern when estimating the path model. The structural model comprised two hypothesised mediating variables. Variance accounted for (VAF) values were calculated to examine to what extent the applicable constructs were explained by the indirect relationships via the applicable mediator variables.

Pertaining to convergent validity, the average variance extracted values ranged between 0.50 and 0.73 . Except for the heterotrait-monotrait ratio between relational CSR practices and discretionary CSR practices of 0.98 and 1.12 between relational CSR practices and moral CSR practices, the other ratios were less than 0.90 for discriminant validity. Apart from relational CSR practices (Cronbach alpha: 0.51) and discretionary CSR practices (Cronbach alpha: 0.64) that were only measured by two items, all other variables had Cronbach alpha values above 0.7 . The composite reliability values ranged between 0.80 and 0.90 , reflecting acceptable internal consistency reliability.

\section{Results and discussion}

The sample consisted of 55\% female and $45 \%$ male respondents. Most respondents were between the ages of 17 and 22 years, with two-thirds of the respondents enrolled in undergraduate programmes. The majority of the respondents formed part of the faculty of Economic and Management Sciences, the largest faculty at this particular university. The sample was deemed representative of the target population in terms of reflecting the university's demographics.

The descriptive statistics for the variables used to estimate brand familiarity, corporate identity, attitude towards CSR practices, CSR familiarity and investment intention will now be provided. Thereafter, the PLS-SEM output will be discussed.

TABLE 3a: Descriptive findings for brand familiarity and corporate identity.

\begin{tabular}{lccccc}
\hline Construct & Median & Mean & $\begin{array}{c}\text { Standard } \\
\text { deviation }\end{array}$ & $\begin{array}{c}\text { 25th } \\
\text { percentile }\end{array}$ & $\begin{array}{c}\text { 75th } \\
\text { percentile }\end{array}$ \\
\hline Brand familiarity & 4.00 & 3.96 & $\mathrm{n} / \mathrm{a}$ & $\mathrm{n} / \mathrm{a}$ & $\mathrm{n} / \mathrm{a}$ \\
Corporate expertise & 3.75 & 3.70 & 0.66 & 3.25 & 4.25 \\
Corporate values & 3.25 & 3.34 & 0.7 & 3.00 & 3.75 \\
\hline
\end{tabular}

TABLE 3b: Descriptive findings for corporate identity.

\begin{tabular}{lclc}
\hline Corporate expertise traits & $\begin{array}{c}\text { Average } \\
\text { score }\end{array}$ & Corporate values traits & $\begin{array}{c}\text { Average } \\
\text { score }\end{array}$ \\
\hline Expert & 3.59 & Activist for change & 3.07 \\
Innovative & 3.34 & $\begin{array}{l}\text { Compassionate (societal } \\
\text { well-being) }\end{array}$ & 3.24 \\
Skilled employees & 3.60 & $\begin{array}{l}\text { Sincere (caring for } \\
\text { stakeholders) }\end{array}$ & 3.30 \\
Experienced & 4.27 & Trustworthy & 3.75 \\
\hline
\end{tabular}




\section{Descriptive statistics}

The descriptive findings for brand familiarity and corporate identity are reported in Table $3 a$ and Table $3 b$. Respondents were asked to rate their familiarity with Nedbank. The relatively high mean brand familiarity score of 3.96 is close to 4.00 signifying that the respondents were familiar with the company and were able to provide meaningful responses to the company-specific questions included in the remainder of the questionnaire.

Corporate identity was evaluated by presenting respondents with four company traits per dimension, as indicated in Table 1. The descriptive results are reported in Table $3 a$ and Table $3 b$. The average scores for the expert, innovative and skilled employees' traits were higher than three, indicating that the respondents were of the view that each trait at least described the company 'to some extent'. Furthermore, the average score for the experienced trait was higher than four, indicating that the respondents viewed Nedbank as very experienced in the banking sector. The respondents perceived each corporate value trait to somewhat describe Nedbank (all average scores were above three). The majority of the respondents perceived Nedbank to be very trustworthy, as indicated by the average score of 3.75. The potential young investors who were surveyed perceived Nedbank to perform better on the corporate expertise dimension (median: 3.75; mean: 3.70) than the corporate values dimension (median: 3.25 ; mean: 3.34$)$. The overall average corporate identity score of 3.52 confirmed that the respondents had a positive perception of Nedbank.

Respondents were presented with 13 CSR practices (as shown in Table 2) and requested to rate the perceived importance of each practice in general (results reported in Table $4 \mathrm{a}$ and Table $4 b$ ). Thereafter, they were requested to rate the perceived performance of Nedbank on each practice (results also reported in Table $4 \mathrm{a}$ and Table $4 \mathrm{~b}$ ). The respondents had

\begin{tabular}{lccccc} 
TABLE 4a: Descriptive findings for corporate social responsibility practices. \\
\hline Variable & Median & Mean & $\begin{array}{c}\text { Standard } \\
\text { deviation }\end{array}$ & $\begin{array}{c}\text { 25th } \\
\text { percentile }\end{array}$ & $\begin{array}{c}\text { 75th } \\
\text { percentile }\end{array}$ \\
\hline CSR attitude in general & 4.46 & 4.32 & 0.60 & 4.08 & 4.77 \\
$\begin{array}{l}\text { CSR attitude towards } \\
\text { Nedbank }\end{array}$ & 3.46 & 3.43 & 0.67 & 3.15 & 3.64 \\
CSR familiarity & 2.33 & 2.32 & 1.09 & 1.00 & 3.33 \\
\hline
\end{tabular}

TABLE 4b: Descriptive findings for corporate social responsibility practices.

\begin{tabular}{lcc}
\hline $\begin{array}{l}\text { CSR } \\
\text { practices }\end{array}$ & $\begin{array}{c}\text { Average score for attitude } \\
\text { towards CSR practices in general }\end{array}$ & $\begin{array}{c}\text { Average score for attitude towards } \\
\text { Nedbank's CSR practices }\end{array}$ \\
\hline 1 & 4.14 & 3.46 \\
2 & 3.74 & 3.01 \\
3 & 4.57 & 3.80 \\
4 & 4.68 & 3.90 \\
5 & 4.54 & 3.46 \\
6 & 4.59 & 3.54 \\
7 & 4.61 & 3.68 \\
8 & 4.07 & 2.90 \\
9 & 4.13 & 3.00 \\
10 & 4.42 & 3.27 \\
11 & 3.88 & 3.45 \\
12 & 4.21 & 3.53 \\
13 & 4.70 & 3.60 \\
\hline
\end{tabular}

CSR, corporate social responsibility. a very favourable attitude towards CSR initiatives in general (median: 4.46; mean: 4.32). This result is supported by the small standard deviation. The respondents for the current study specifically deemed it very important that a business should not engage in unethical practices (CSR practice 13) and respect human rights (CSR practice 4 ). The respondents perceived Nedbank to perform average on most CSR practices (median: 3.46; mean: 3.34). They felt that Nedbank performed well on not producing harmful products (CSR practice 3) and respecting human rights (CSR practice 4). However, they were concerned about Nedbank's ability to address climate change (CSR practice 8 ) and report on their environmental impact (CSR practice 9). The perceptual scores were then combined into three categories, namely discretionary (CSR practices 1 and 2; mean score: 3.24), moral (CSR practices 3-8, 10, 11 and 13; mean score: 3.51) and relational practices (CSR practices 9 and 12; mean score: 3.27 ).

The respondents' degree of familiarity with three of Nedbank's actual CSR practices was also measured. Despite substantial corporate investment in these initiatives, many of the potential young investors surveyed indicated that they were 'not at all familiar' with these initiatives. The mean (2.32) and median (2.33) for CSR familiarity presented in Table 4a and Table $4 \mathrm{~b}$ were below 3.00, indicating that the majority of the respondents were only 'somewhat familiar' with Nedbank's CSR initiatives. The standard deviation supports this finding by indicating that most of the data points are within 1.09 units of the mean.

The respondents' intention to invest in Nedbank's shares was measured at three distinct points in the questionnaire. They were first asked how likely they were to invest in Nedbank's shares right after they rated their perception of Nedbank's CSR performance (pertaining to the 13 CSR practices). At this point, the respondents had not yet been presented with any information regarding the company's actual CSR performance. As indicated in Table 5, the largest group of respondents $(37.35 \%)$ indicated that they felt 'neutral' as to whether they would invest, whilst only a few were 'very likely' to invest at this stage. Their investment intention at this stage is confirmed by the average response of 3.17 .

Secondly, respondents were requested to indicate how likely they were to invest in Nedbank's shares after they were presented with details on its actual CSR initiatives. For scenario $2,62 \%$ of the respondents indicated that they were likely or very likely to invest in Nedbank's shares. The

\begin{tabular}{|c|c|c|c|c|c|c|}
\hline Frequency per scenario & $\begin{array}{l}\text { 1: Very } \\
\text { unlikely }\end{array}$ & $\begin{array}{c}\text { 2: } \\
\text { Unlikely }\end{array}$ & $\begin{array}{l}\text { 3: } \\
\text { Neutral }\end{array}$ & $\begin{array}{c}\text { 4: } \\
\text { Likely }\end{array}$ & $\begin{array}{l}\text { 5: Very } \\
\text { likely }\end{array}$ & Average \\
\hline $\begin{array}{l}\text { Scenario 1: Perceived CSR } \\
\text { performance of Nedbank }\end{array}$ & 126 & 245 & 616 & 542 & 120 & 3.17 \\
\hline $\begin{array}{l}\text { Scenario 2: After } \\
\text { provision of details on } \\
\text { Nedbank CSR practices }\end{array}$ & 91 & 130 & 405 & 722 & 301 & 3.61 \\
\hline $\begin{array}{l}\text { Scenario 3: After } \\
\text { provision of Nedbank } \\
\text { CSR score }\end{array}$ & 79 & 103 & 275 & 797 & 395 & 3.80 \\
\hline
\end{tabular}

CSR, corporate social responsibility. 


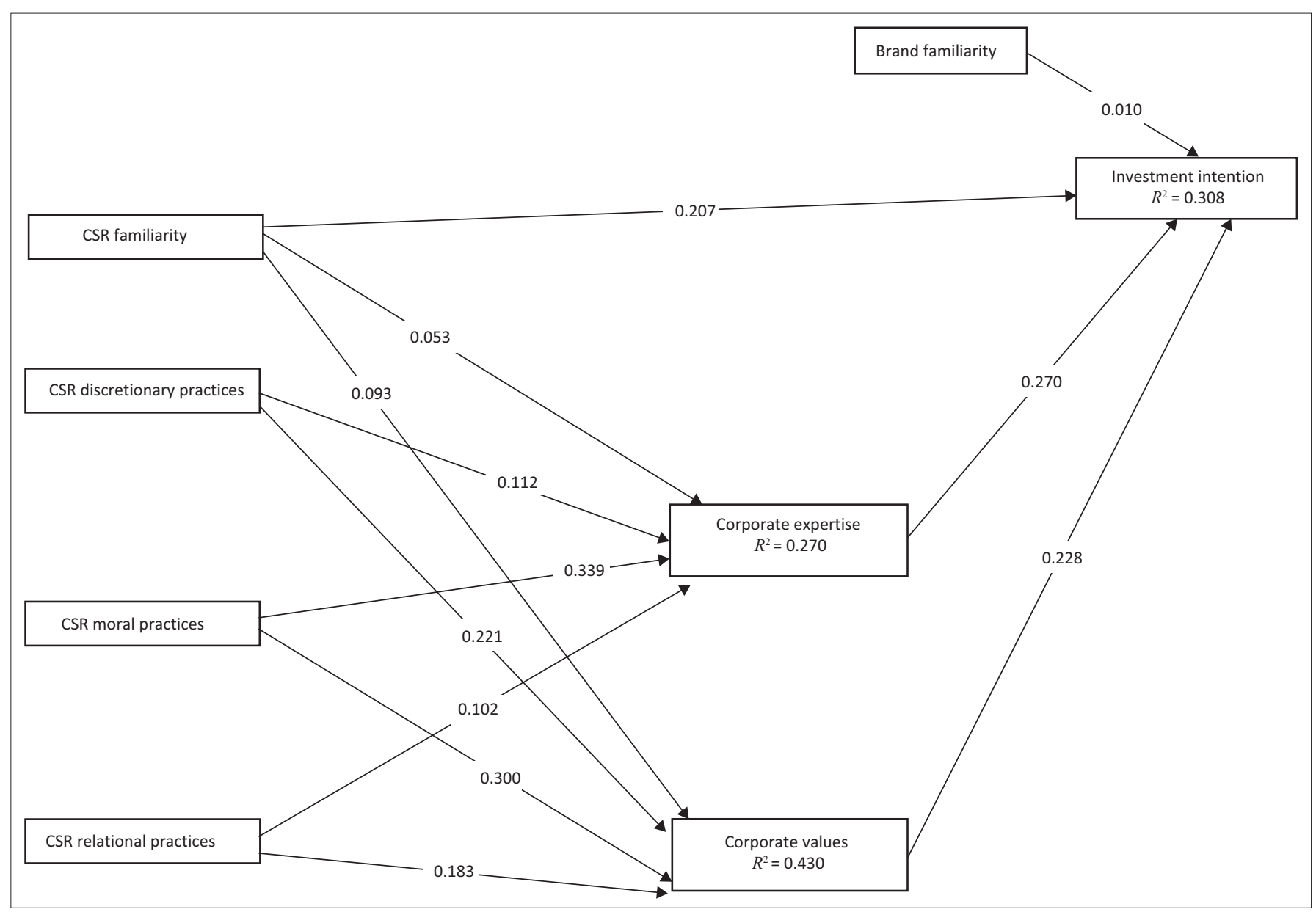

FIGURE 1: Structural model.

average increased to 3.61 (from 3.17 in scenario 1). Finally, respondents were once again asked how likely they were to invest in Nedbank's shares after they were provided with a concrete CSR score of $88 \%$ (where $0 \%$ indicates that there is no evidence of CSR practices and 100\% represents an outstanding CSR score). As shown in Table 5, 72\% of the respondents were likely or very likely to invest at this stage. As such, once the potential young investors became more familiar with the company's CSR practices, their intention to invest increased, supported by the average value of 3.80 in scenario 3.

\section{Structural model assessment}

Partial least squares structural equation modelling was used to assess the structural model presented in Figure 1.

The $R$-squared values for corporate expertise and corporate values shown in Figure 1 indicate that approximately $27 \%$ and $43 \%$ of the variance in these variables can be explained by exogenous variables, namely discretionary, moral and relational CSR practices as well as CSR familiarity. The focus should be placed on familiarising investors with CSR practices, given the considerable influence thereof on corporate values which, in turn, influenced approximately $31 \%$ of investment intention amongst the potential young investors.
TABLE 6: Path coefficients between constructs.

\begin{tabular}{|c|c|c|c|c|c|c|}
\hline Path (relationship) & & & Path & $95 \% \mathrm{Cl}$ & $95 \% \mathrm{Cl}$ & \\
\hline $\begin{array}{l}\text { Discretionary CSR } \\
\text { practices }\end{array}$ & $\rightarrow$ & Corporate expertise & 0.11 & 0.05 & 0.17 & 0.00 \\
\hline $\begin{array}{l}\text { Discretionary CSR } \\
\text { practices }\end{array}$ & $\rightarrow$ & Corporate values & 0.22 & 0.17 & 0.28 & 0.00 \\
\hline $\begin{array}{l}\text { Moral CSR } \\
\text { practices }\end{array}$ & $\rightarrow$ & Corporate expertise & 0.34 & 0.27 & 0.41 & 0.00 \\
\hline $\begin{array}{l}\text { Moral CSR } \\
\text { practices }\end{array}$ & $\rightarrow$ & Corporate values & 0.30 & 0.23 & 0.37 & 0.00 \\
\hline $\begin{array}{l}\text { Relational CSR } \\
\text { practices }\end{array}$ & $\rightarrow$ & Corporate expertise & 0.10 & 0.04 & 0.16 & 0.00 \\
\hline $\begin{array}{l}\text { Relational CSR } \\
\text { practices }\end{array}$ & $\rightarrow$ & Corporate values & 0.18 & 0.12 & 0.25 & 0.00 \\
\hline $\begin{array}{l}\text { Corporate } \\
\text { expertise }\end{array}$ & $\rightarrow$ & Investment intention & 0.27 & 0.21 & 0.33 & 0.00 \\
\hline Corporate values & $\rightarrow$ & Investment intention & 0.23 & 0.17 & 0.29 & 0.00 \\
\hline CSR familiarity & $\rightarrow$ & Corporate expertise & 0.05 & 0.01 & 0.10 & 0.03 \\
\hline CSR familiarity & $\rightarrow$ & Corporate values & 0.09 & 0.05 & 0.13 & 0.00 \\
\hline CSR familiarity & $\rightarrow$ & Investment intention & 0.21 & 0.16 & 0.25 & 0.00 \\
\hline Brand familiarity & $\rightarrow$ & Investment intention & 0.01 & -0.03 & 0.05 & 0.66 \\
\hline
\end{tabular}

$\mathrm{Cl}$, confidence interval; CSR, corporate social responsibility.

The significance of the measurement items was determined by considering the standard errors that were obtained through the nonparametric bootstrapping procedure. The paths between the measurement items and the relevant constructs were statistically significant because none of the 
confidence intervals (CIs) contained zero. The results confirm that each item included in the respective construct scales measured what it was intended to measure.

Table 6 indicates the significance of the path coefficients between the constructs. To determine the stability of the path coefficients, 95\% CIs (denoted as CI upper and lower) were calculated.

The path analyses between the constructs suggest that CSR practices are significant predictors of both corporate identity dimensions. Previous researchers confirmed that CSR activities have a positive impact on corporate identity (Maignan \& Ferell 2004; Maruf 2013; Meehan, Meehan \& Richards 2006; Pomering \& Johnson 2009; Poolthong \& Mandhachitara 2009). The results reported in Table 6 suggest that discretionary and relational CSR practices have stronger predictor relevance for corporate values than for corporate expertise. Moral CSR practices had substantial prediction relevance towards both corporate expertise and corporate values, suggesting that companies that engage in moral CSR activities could simultaneously improve two dimensions of corporate identity. As such, CSR seems to play a central role in predicting the corporate identity of Nedbank.

Although corporate expertise (path coefficient: 0.27) had a larger influence on investment intention than corporate values (path coefficient: 0.23 ), the results confirmed that the latter still plays an important role in investment decision-making. Shamma and Hassan (2009) likewise found that stakeholders' perception of vision, leadership and emotional appeal had a significant positive impact on behavioural intention.

According to Brown and Dacin (1997), the primary influence of CSR perception on behavioural attributes is evident through the former's influence on the corporate identity mediator. Both dimensions of corporate identity have mediated the link between CSR practices and investment intention (refer to Figure 1). Each of the considered CSR practices had a stronger indirect effect on investment intention through corporate values than through corporate expertise. The considered potential young investors' perceptions of CSR practices hence seem to have impacted their perception of corporate values, which, in turn, had an effect on their investment intention. Therefore, as predicted by the theory of planned behaviour (Ajzen 1991), the perceptions of CSR practices of a well-known South African company have influenced the sampled young individuals' intention to invest. This outcome corresponds to Arikan et al. (2016), who found that the relationship between prospective investors' CSR perceptions and their intention to invest has been partially mediated by their perceptions of corporate reputation.

The VAF value of $6 \%$ revealed that the effect of CSR familiarity on investment intention is not mediated by corporate expertise. In addition, the corporate values dimension of corporate identity is also not deemed a mediator between CSR familiarity and investment intention (VAF: 9\%).
In contrast, the direct path between CSR familiarity and investment intention was significant. Alniacik et al. (2011) likewise noted that awareness of a firm's CSR initiatives enhances stakeholders' intention to buy its shares. The provision of information about a particular company's CSR activities is thus likely to enhance investor intention.

Brand familiarity did not have a significant impact on the investment intention of the respondents. This result contradicts the literature showing that individuals tend to invest in the shares of a company based on their familiarity with the company (Aspara \& Tikkanen 2008; De Bondt, Mayoral \& Vallelado 2013; De Vries, Erasmus \& Gerber 2017; Huberman 2001; Lim et al. 2013; Subrahmanyam 2008). The brand familiarity of Nedbank was very high amongst respondents, with very little variance. Respondents were therefore presumed to express an informed opinion when answering company-related questions. However, it seems that this high degree of familiarity contributed to the insignificant result. Except for hypotheses 15, 16 and 18, all other alternative hypotheses were supported.

\section{Conclusion and recommendations}

Whilst there is a substantial body of knowledge on traditional investment considerations such as risk and return, the impact of attitude and its perceptual component on investor behaviour warrants more attention. Literature suggests that there are several factors that could impact investors' perceptions of a company which, in turn, could influence their investment intent. Furthermore, a strong corporate identity can help companies to attract investors, as well as consumers (Maden, Arikan \& Telci 2012; Melewar \& Karaosmanoglu 2006; Shamma \& Hassan 2009). The theory of planned behaviour was hence used to investigate the impact of CSR perception on investor intention in South Africa.

David et al. (2005) developed a dual-process model to investigate the effect of perception of tangible (corporate expertise) and intangible (corporate values) dimensions of corporate identity and CSR practices on purchasing intention. Young individuals are particularly sensitive to CSR issues (deVere Group 2020; Sen et al. 2006). This study makes a methodological contribution as it is the first study to apply a dual-process model that was developed based on consumer behavioural constructs to assess the role that perception of corporate identity and CSR practices play in the investment intention of potential young investors in South Africa.

David et al.'s (2005) adapted dual-process model was found to be valid and reliable in the investor context. The PLS-SEM results showed that discretionary, moral and relational CSR practices have a positive effect on both dimensions of corporate identity. However, discretionary and relational CSR practices have more predictive relevance towards corporate values than corporate expertise. Both the corporate identity dimensions were strongly predicted by moral CSR 
practices. In turn, the perception of both corporate identity dimensions strongly predicted investment intention. Although corporate expertise and corporate values acted as mediators between the considered CSR practices and investment intention, the predictive relevance was small. The effect of CSR familiarity on investment intention was neither mediated by corporate values nor by corporate expertise. Whilst CSR familiarity had a direct positive effect on investment intention, brand familiarity did not have a significant effect on investment intention. The results hence show support for the application of the theory of planned behaviour in the investment context.

Based on these results, communication and marketing teams are encouraged to commence with their companies' CSR journeys by addressing moral CSR practices. They could consider blogs, podcasts, forums and other social media platforms, in addition to websites, to facilitate informal discussions with investors and other stakeholders on CSR considerations. Actual and potential investors are encouraged to use such platforms to voice their CSR concerns. Internal auditors could receive (more) training to ensure clear(er) stakeholder communication.

Training on ethical decision-making and the prevention of corruption could be considered for various employment levels. In addition to mainstream finance courses, tertiary education institutions are encouraged to offer short courses on financial literacy, behavioural finance and CSR to educate potential young investors from different backgrounds on how to approach investment opportunities in a responsible manner.

This study has four limitations. Firstly, only one wellknown company was used to test the adapted model in the South African investment context. Researchers are therefore encouraged to incorporate companies that operate in diverse industries when they investigate behavioural intention in future. Secondly, the sample comprised students who were deemed prospective investors. It is acknowledged that students' investing experiences are likely to be more limited than those of working adults. Future researchers could hence focus on non-student respondents when conducting behavioural studies. Thirdly, self-selection bias might have occurred, as individuals who feel more strongly about CSR might have been more likely to respond to the survey. To address this limitation, qualitative data collection or a mixed methods approach could be employed in future studies to assess whether trends related to CSR, familiarity and investment intention change over time. Fourthly, as brand familiarity and investment intention were measured by single items in the employed model, it is suggested that future authors include more items to measure these aspects.

The findings emphasised that enhanced focus on CSR is beneficial and can create shared value for companies and investors. Companies and potential investors are encouraged to increase their investment in CSR practices and make (more) ethical investment decisions.

\section{Acknowledgements Competing interests}

The authors declare that they have no financial or personal relationships that may have inappropriately influenced them in writing this article.

\section{Authors' contributions}

K.N., P.D.E. and N.M.-K. conceptualised the article; K.N. prepared the draft manuscript, including the methodology and data analysis; K.N., P.D.E. and N.M.-K. edited and finalised the manuscript; P.D.E. and N.M.-K. supervised the research process; and K.N. rendered project administration.

\section{Ethical considerations}

The study was approved by the Research Ethics Committee of Stellenbosch University (REC-2019-9986, IRPSD-1345 IRPSD-1581). Institutional permission was also granted. Informed consent was obtained from all subjects involved in this study.

\section{Funding information}

This research received no specific grant from any funding agency in the public, commercial or not-for-profit sectors.

\section{Data availability}

The raw data cannot be made available because of ethical restrictions.

\section{Disclaimer}

The views and opinions expressed in this article are those of the authors and do not necessarily reflect the official policy or position of any affiliated agency of the authors.

\section{References}

Adam, A.A. \& Shauki, E.R., 2014, 'Socially responsible investment in Malaysia: Behavioral framework in evaluating investors' decision making process', Journal of Cleaner Production 80(1), 224-240. https://doi.org/10.1016/j. jclepro.2014.05.075

Ajzen, I., 1989, 'Attitude structure and behaviour', in A.R. Pratkanis, S.J. Breckler \& A.G. Greenwald (eds.), Attitude structure and function, pp. 241-274, Lawrence Erlbaum Associates Hillsdale, MI.

Ajzen, I., 1991, 'The theory of planned behavior', Organizational Behavior and Human Decision Processes 50(2), 179-211. https://doi.org/10.1016/07495978(91)90020-T

Albarracin, D., 2002, 'Cognition in persuasion: An analysis of information processing in response to persuasive communications', Advances in Experimental Social Psychology 34(1), 61-130. https://doi.org/10.1016/S0065-2601(02)80004-1

Alleyne, P. \& Broome, T., 2011, 'Using the theory of planned behaviour and risk propensity to measure investment intentions amongst future investors', Journal of Eastern Caribbean Studies 36(1), 1-20.

Alniacik, U., Alniacik, E. \& Genc, N., 2011, 'How corporate social responsibility information influences stakeholders' intentions', Corporate Social Responsibility and Environmental Management 18(4), 234-245. https://doi.org/10.1002/ csr.245

Arikan, E., Kantur, D., Maden, C. \& Telci, E.E., 2016, 'Investigating the mediating role of corporate reputation on the relationship between corporate social responsibility and multiple stakeholder outcomes', Quality \& Quantity 50(1), 129-149. https:// doi.org/10.1007/s11135-014-0141-5

Aspara, J. \& Tikkanen, H., 2008, 'Interactions of individuals' company-related attitudes and their buying of companies' stocks and products', The Journal of Behavioral Finance 9(2), 85-94. https://doi.org/10.1080/15427560802107462 
Aspara, J. \& Tikkanen, H., 2010, 'Consumers' stock preferences beyond expected financial returns: The influence of product and brand evaluations', International Journal of Bank Marketing 28(3), 193-221. https://doi.org/10.1108/02652321011036468

Bhattacharya, C.B., Sen, S. \& Korschun, D., 2008, 'Using corporate social responsibility to win the war for talent', MIT Sloan Management Review 49(2), 37-44.

Brown, E., 2015, Take your soul to work: 365 meditations on every day leadership, Simon and Schuster, New York, NY.

Brown, T.J. \& Dacin, P.A., 1997, 'The company and the product: Corporate associations and consumer product responses', Journal of Marketing 61(1), 68-84. https://doi. org/10.1177/002224299706100106

Carroll, A.B., 1979, 'A three dimensional conceptual model of corporate socia performance', Academy of Management Review 4(4), 497-505. https://doi. org/10.5465/amr.1979.4498296

Carroll, A.B. \& Buchholtz, A.K., 2015, Business and society: Ethics, sustainability, and stakeholder management, Cengage Learning, Stamford, CT.

Clark-Murphy, M. \& Soutar, G.N., 2004, 'What individual investors value: Some Australian evidence', Journal of Economic Psychology 25(4), 539-555. https://doi. org/10.1016/S0167-4870(03)00056-4

Connelly, B.L., Certo, S.T., Ireland, R.D. \& Reutzel, C.R., 2011, 'Signaling theory: A review and assessment', Journal of Management 37(1), 39-67. https://doi. org/10.1177/0149206310388419

CSRHub, 2019, Software and database, viewed 01 March 2019, from https://www. csrhub.com/.

David, P., Kline, S. \& Dai, Y., 2005, 'Corporate social responsibility practices, corporate identity and purchase intention: A dual-process model', Journal of Public Relations Research 17(3), 291-313. https://doi.org/10.1207/s1532754xjprr1703_4

De Bondt, W., Mayoral, R.M. \& Vallelado, E., 2013, 'Behavioral decision-making in finance: An overview and assessment of selected research', Spanish Journal of Finance and Accounting 42(157), 99-118. https://doi.org/10.1080/02102412.201 Finance and

deVere Group, 2020, 8 out of 10 millennials now prioritise responsible investing - And they're right, viewed 25 April 2020, from https://www.devere-group.com/news/8out-of-10-millennials-now-prioritise-responsible-investing-and-theyre-right.aspx.

De Vries, A., Erasmus, P.D. \& Gerber, C., 2017, 'The familiar versus the unfamiliar: Familiarity bias amongst individual investors', Acta Commercii 17(1), 1-10. https://doi.org/10.4102/ac.v17i1.366

Diamantopoulos, A.B., Schlegelmilch, B., Sinkovics, R.R. \& Bohlen, G., 2003, 'Can sociodemographics still play a role in profiling green consumers? A review of the evidence and an empirical investigation', Journal of Business Research 56(6), 465480. https://doi.org/10.1016/S0148-2963(01)00241-7

Disparte, D.A. \& Gentry, T., 2015, Corporate activism is on the rise, viewed 12 March 2019, from https://intpolicydigest.org/2015/07/06/corporate-activism-is-on-therise/.

Dowling, G.R. \& Moran, P., 2012, 'Corporate reputations: Built in or bolted on?' California Management Review 54(2), 25-42. https://doi.org/10.1525/ cmr.2012.54.2.25

East, R., 1993, 'Investment decisions and the theory of planned behaviour', Journal of Economic Psychology 14(2), 337-375. https://doi.org/10.1016/0167 of Economic Psych

Erasmus, P.D., 2017 'As simple as ABC? The impact of attitude on investment decisionmaking', in Proceedings of the 29th Southern Africa Institute for Management Scientists conference, Bloemfontein, September 10-12.

Fishbein, M. \& Ajzen, I., 1975, Belief, attitude, intention and behaviour, Addison Wesley, Reading, MA.

Foley, H. \& Matlin, M., 2010, Sensation and perception, Pearson Education, Boston, MA.

Frieder, L. \& Subrahmanyam, A., 2005, 'Brand perceptions and the market for common stock', Journal of Financial and Quantitative Analysis 40(1), 57-85. https://doi. org/10.1017/S0022109000001745

Henning, E., Van Rensburg, W. \& Smit, B., 2004, Finding your way in qualitative research, Van Schaik, Pretoria.

Hogg, M. \& Vaughan, G., 2008, Social psychology, Pearson Education Limited, Essex.

Huberman, G., 2001, 'Familiarity breeds investment', The Review of Financial Studies 14(3), 659-680. https://doi.org/10.1093/rfs/14.3.659

Jain, V., 2014, '3D model of attitude', International Journal of Advanced Research in Management and Social Sciences 3(3), 1-12.

Junkus, J.C. \& Berry, T.C., 2010, 'The demographic profile of socially responsible investors', Managerial Finance 36(6), 474-481. https://doi.org/10.1108/03074351011042955

Kurucz, E.C., Colbert, B.A. \& Wheeler, D., 2008, 'The business case for corporate social responsibility', in A. Crane, A. McWilliams, D. Matten, J. Moon \& D.S. Siegel (eds.) The Oxford handbook of corporate social responsibility, pp. 83-112, Oxford University Press, New York, NY.

Lim, K.L., Soutar, G.N. \& Lee, J.A., 2013, 'Factors affecting investment intention: A consumer behavior perspective', Journal of Financial Services Marketing 18(4), 301-315. https://doi.org/10.1057/fsm.2013.23
Mackey, A., Mackey, T.B. \& Barney, J.B., 2007, 'Corporate social responsibility and firm performance: Investor preferences and corporate strategies', Academy of Management Review 32(2), 817-835. https://doi.org/10.5465/amr.2007.25275676

Maden, C., Arikan, E., Telci, E.E. \& Kantur, D., 2012, ‘Linking corporate social responsibility to corporate reputation: A study on understanding behavioral consequences', in Proceedings of the 8th international strategic management conference, Barcelona, June 21-23.

Maignan, I. \& Ferrell, O.C., 2004, 'Corporate social responsibility and marketing: An integrative framework', Journal of the Academy of Marketing Science 32(1), 3-19. https://doi.org/10.1177/0092070303258971

Maio, G.R. \& Haddock, G., 2015, The psychology of attitudes and attitude change, Sage, London.

Maruf, A.A., 2013, 'Corporate social responsibility and corporate image', Transnational Journal of Science and Technology 3(8), 29-49.

Meehan, J., Meehan, K. \& Richards, A., 2006, 'Corporate social responsibility: The 3CSR model', International Journal of Social Economics 33(5), 386-398. https://doi. org/10.1108/03068290610660661

Meier, S. \& Cassar, L., 2018, Stop talking about how CSR helps your bottom line, viewed 19 January 2019, from https://hbr.org/2018/01/stop-talking-about-how-csrhelps-your-bottom-line.

Melewar, T.C. \& Karaosmanoglu, E., 2006, 'Seven dimensions of corporate identity: A categorisation from the practitioners' perspectives', European Journal of categorisation from the
Marketing $40(7), 846-869$.

Nilsson, J., 2008, 'Investment with a conscience: Examining the impact of pro-social attitudes and perceived financial performance on socially responsible investment behaviour', Journal of Business Ethics 83(2), 307-325. https://doi.org/10.1007/ s10551-007-9621-z

Oswald, D., 2010, Sincerity is strength, viewed12 March 2019, from https:// hrdailyadvisor.blr.com/2010/04/29/sincerity-is-strength/.

Parumasur, A.B. \& Roberts-Lombard, M., 2014, Consumer behaviour, Juta, Cape Town.

Pérez, A. \& Rodríguez del Bosque, I.R., 2012, 'The role of CSR in the corporate identity of banking service providers', Journal of Business Ethics 108(2), 145-166. https:// doi.org/10.1007/s10551-011-1067-7

Pomering, A.A. \& Johnson, L.W., 2009, 'Advertising corporate social responsibility initiatives to communicate corporate image: Inhibiting scepticism to enhance persuasion', Corporate Communications: An International Journal 14(4), 420-439. https://doi.org/10.1108/02652320910988302

Poolthong, Y. \& Mandhachitara, R., 2009, 'Customer expectations of CSR, perceived service quality and brand effect in Thai retail banking', International Journal of Bank Marketing 27(6), 408-427.

Porter, M.E. \& Kramer, M.R., 2006, 'The link between competitive advantage and corporate social responsibility', Harvard Business Review 84(12), 78-92.

Porter, M.E. \& Kramer, M.R., 2011, 'Creating shared value', Harvard Business Review 89(1), 62-77.

Reitz, H.J., 1977, Behavior in organizations, Irwin, Homewood, IL.

Schiffman, L.G. \& Kanuk, L.L., 2010, Consumer behaviour, Prentice Hall, Upper Saddle River, NJ.

Schmidt, C., 1995, The quest for identity., Cassell, London.

Scott, J., 2000, 'Rational choice theory', in G. Browning, A. Halcli \& F. Webster (eds.), Understanding contemporary society: Theories of the present, pp. 671-685, Sage, Thousand Oaks, CA.

Sen, S. \& Bhattacharya, C.B., 2001, 'Does doing good always lead to doing better? Consumer reactions to corporate social responsibility', Journal of Marketing Research 38(2), 225-243.

Sen, S., Bhattacharya, C.B. \& Korschun, D., 2006, 'The role of corporate social responsibility in strengthening multiple stakeholder relationships: A field experiment', Journal of the Academy of Marketing Science 34(2), 158-166. https://doi.org/10.1177/0092070305284978

Shamma, H.M. \& Hassan, S.S., 2009, 'Customer and non-customer perspectives for examining corporate reputation', Journal of Product and Brand Management 18(5), 326-337. https://doi.org/10.1108/10610420910981800

Statman, M., 2004, 'What do investors want?', The Journal of Portfolio Management 30(5), 153-161. https://doi.org/10.3905/jpm.2004.442641

Subrahmanyam, A., 2008, 'Behavioural finance: A review and synthesis', European Financial Management 14(1), 12-29.

Turban, D.B. \& Greening, D.W., 1997, 'Corporate social performance and organizational attractiveness to prospective employees', Academy of Management Journal 40(3), 658-672. https://doi.org/10.2307/257057

Valdellon, L., 2018, Compassion isn't a soft leadership skill. It's a crucial power skill, viewed 12 March 2019, from https://medium.com/@WriterLionel/compassionisnt-a-soft-leadership-skill-it-s-a-crucial-power-skill-4c828e2d24af.

Wittmer, D. \& O'Brien, K., 2014, 'The virtue of "virtue ethics" in business and business education', Journal of Business Ethics Education 11(1), 261-278. https://doi. org/10.5840/jbee20141113

Zikmund, W.G., Babin, B.J., Carr, J.C. \& Griffin, M., 2013, Business research methods, South-Western Cengage Learning, Mason, $\mathrm{OH}$. 